One Way the Demand for Labor May Adapt to the Availability of Labor

\author{
Harriet Orcutt Duleep
}

Thomas Jefferson Program in Public Policy, College of William and Mary IZA- Institute for the Study of Labor

College of William and Mary

Department of Economics

Working Paper Number 132

March 2013 
COLLEGE OF WILLIAM AND MARY

DEPARTMENT OF ECONOMICS

WORKING PAPER \# 132

March 2013

\title{
One Way the Demand for Labor May Adapt to the Availability of Labor
}

\begin{abstract}
This paper presents and tests a model that may partially explain why the demand for labor adapts to the availability of labor. In particular, I postulate that the cost of hiring declines with increases in the amount of labor available. The cost of hiring would decrease with a growth in available labor for two reasons: (1) individuals seeking employment would be coming to employers instead of the latter seeking them out and (2) the larger set of potential employees would increase the probability of employers finding individuals suitable for unfilled jobs. Moreover, individuals seeking employment may engender employers to think of new ways in which labor can be used. An increase in the number of entrants to the labor force would lower the cost of hiring and increase employment demand at any given wage rate. Hence, a change in the labor force-such as the addition of women or immigrants - does not increase unemployment as much as is predicted for current workers because demand for labor increases as the cost of hiring decreases. The paper may provide some insight into the relationship between the size of the labor force and employment demand as recently highlighted by Stock and Watson in their examination of the 2007-2009 recession.
\end{abstract}

JEL Codes: J23, J21, J11, J32

Keywords: Labor demand, labor supply, cost of hiring

\author{
Harriet Duleep \\ Thomas Jefferson Program in Public Policy \\ College of William and Mary \\ Williamsburg VA 23187-8795 \\ hduleep@wm.edu
}



One Way the Demand for Labor May Adapt to the Availability of Labor

Harriet Orcutt Duleep ${ }^{1}$

This paper explores the following joint hypothesis: the cost of hiring declines with increases in the amount of labor available for employment and the employment decisions of firms are inversely related to the cost of hiring.

The cost of hiring would be expected to decrease with a growth in the available labor supply (either new entrants or unemployed individuals) for two reasons: individuals seeking employment would be coming to employers instead of the latter seeking them out, and the larger set of potential employees would increase the probability of employers finding individuals suitable for unfilled jobs. Moreover, individuals seeking employment may engender employers to think of new ways in which labor can be used. Employment inversely related to hiring costs rests on the assumption that firms minimize costs.

These ideas are clarified in Figures 1 and 2. The cost of hiring, $\mathrm{L}$, is a function of the number of persons in the labor force minus the number employed, LF - E. The broken line in the second diagram represents the traditionally conceived labor demand curve where employment decisions are a function of the wage rate. The continuous line demonstrates the added effect of the cost of hiring, L.

Starting at the equilibrium wage rate, $\mathrm{W}^{*}$, an increase in the wage rate decreases the demand for employment. But this increases the amount of labor available for employment LF - E, which lowers L. The lower value of $\mathrm{L}$ induces additional demand for employment. But additional employment increases L. The process converges somewhere in between, to the right

*This paper was written eons ago. I will never have time to update and complete it and would welcome anyone taking it over or using the model's insights. 


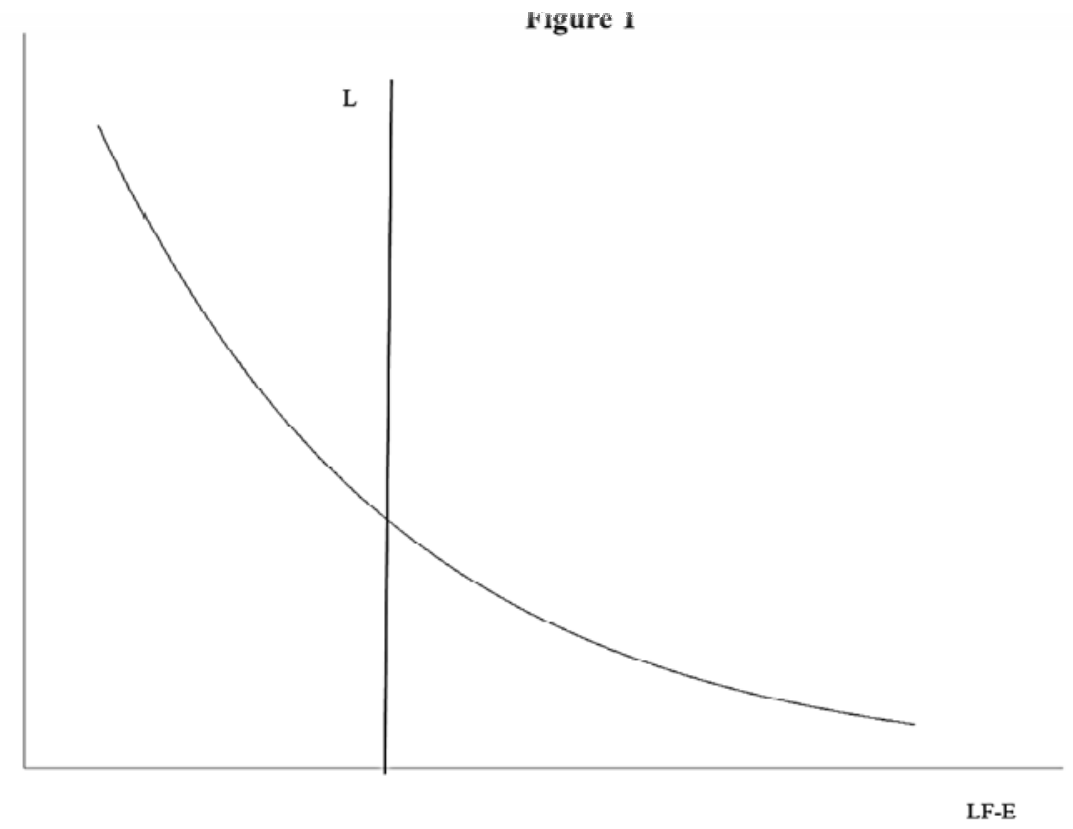

rigure 2

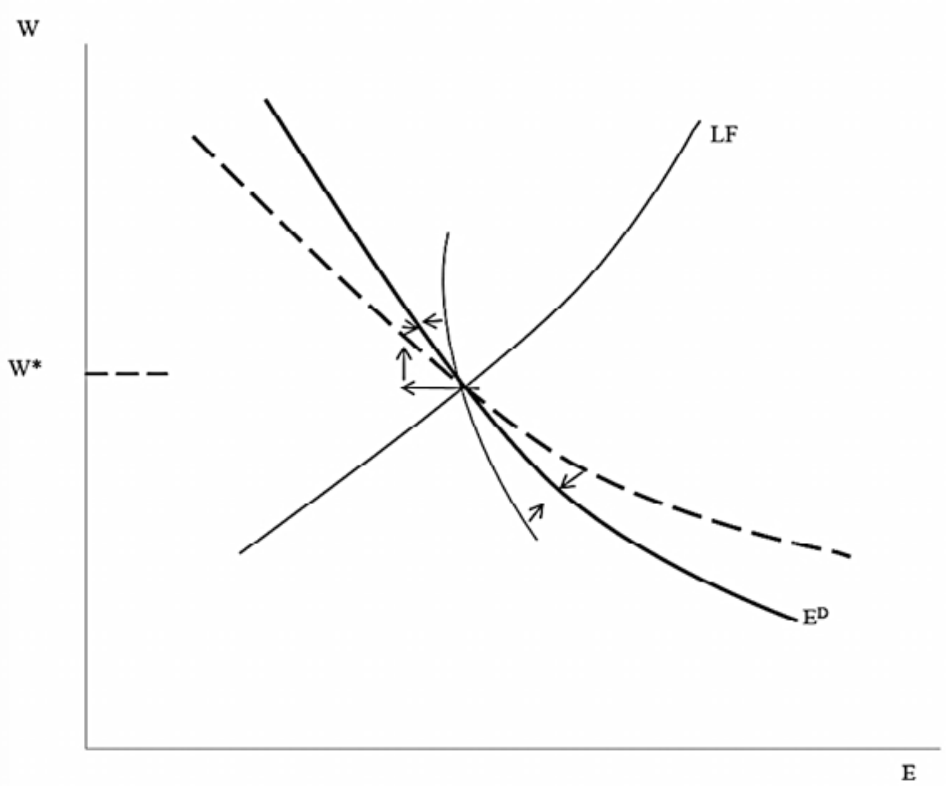


of the original demand curve. Similarly, going below the equilibrium wage rate increases L, which then decreases the demand for employment at any given wage rate.

A shift in the labor supply curve, LF, would also affect the cost of hiring in the same way. For example, an increase in the number of entrants to the labor force would lower L and increase employment demand at any given wage rate.

A process symmetric to the cost of hiring effect occurs from the point of view of labor. An increase in employment or a decrease in the labor force decreases the cost of finding a job, which then increases the labor supply at any given wage rate (see Figure 3). This has been referred to as the "discouraged worker effect." In short, I am proposing a "discouraged employer effect."

Figure 3

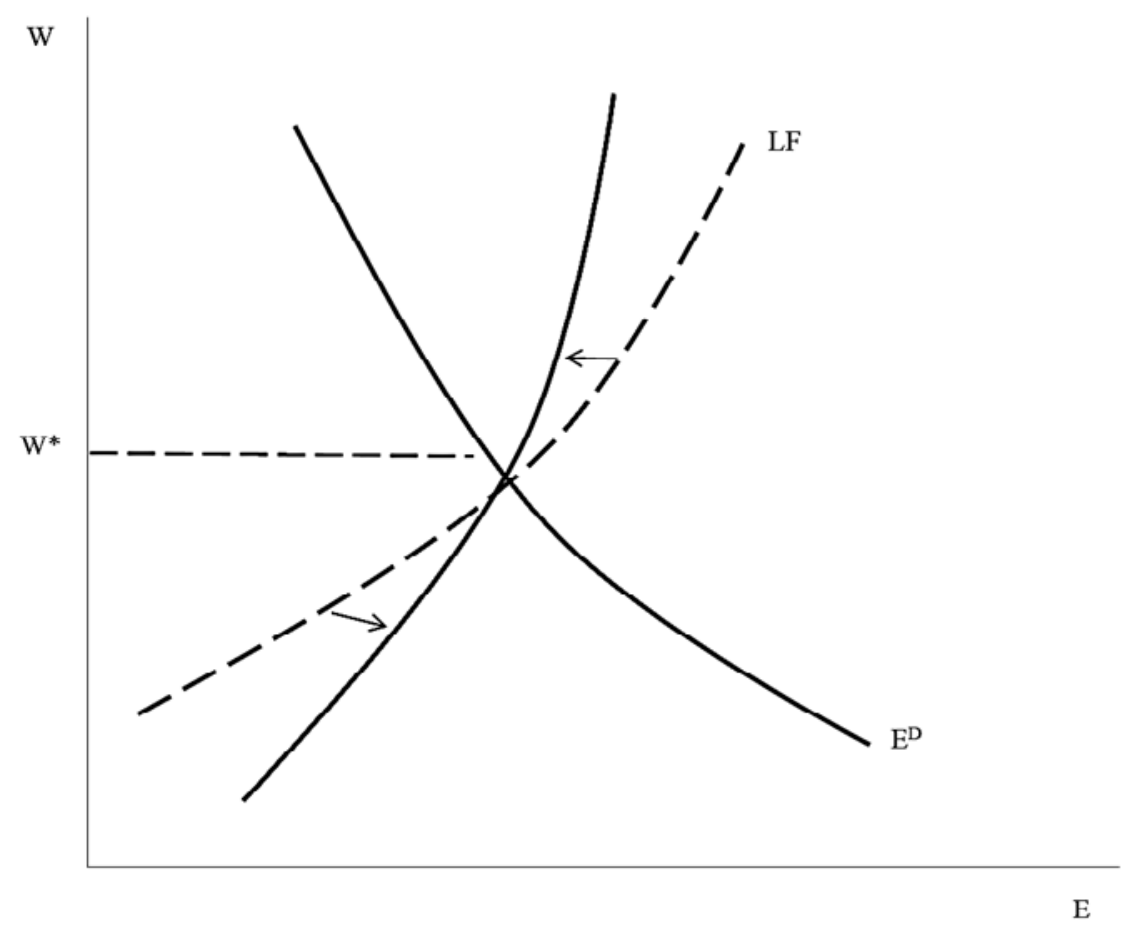


The general state of the labor market is disequilibrium. I have assumed that observed employment is the minimum of the demand and supply of labor. Referring back to Figure 2, the demand for labor is only observed when the wage rate exceeds the equilibrium wage rate.

However, given the difficulty of determining an equilibrium wage rate, I have made assumptions in terms of the percentage of the labor force employed. It is assumed that employers get as much labor as they want up to full employment, defined as $4 \%$ of the labor force unemployed. Beyond this point, the demand for labor is no longer observed. This assumption is highly questionable since it is possible for both labor and employers to be constrained at the same level of unemployment (Structural unemployment may exist.) Even ignoring this consideration, the level of unemployment beyond which employment would not represent labor demand would vary over time. Disregarding these problems, the proposed model is presented below.

$$
\begin{aligned}
& \mathrm{E}=\min \left(\mathrm{E}^{\mathrm{D}}, .96 \mathrm{LF}\right) \\
& \mathrm{E}^{\mathrm{D}}=\beta_{1}+\beta_{2} \mathrm{~W}+\gamma \mathrm{L}_{1}+\beta_{3} \mathrm{Z}+\varepsilon_{1} \\
& \mathrm{LF}=\mathrm{b}_{1}+\mathrm{b}_{2} \mathrm{~W}-\theta \mathrm{L}_{2}+\mathrm{b}_{3} \mathrm{~F}+\varepsilon_{2} \\
& \mathrm{~L}_{1}=\pi_{1}+\eta(\mathrm{LF}-\mathrm{E})+\varepsilon_{3} \\
& \mathrm{~L}_{2}=\pi_{2}+\alpha(\mathrm{LF}-\mathrm{E})+\varepsilon_{4} \\
& \quad \text { Where } \\
& \mathrm{E}=\text { employment } \\
& \mathrm{E}^{\mathrm{D}}=\text { demand for labor } \\
& \mathrm{LF}=\text { the labor force } \\
& \mathrm{W}=\text { the wage rate } \\
& \mathrm{L}_{1}=\text { the cost of hiring labor for employers } \\
& \mathrm{L}_{2}=\text { the cost of locating employment for labor } \\
& \mathrm{Z}=\text { variables affecting the demand for labor } \\
& \mathrm{F}=\text { variables affecting the supply of labor }
\end{aligned}
$$


Support for the hypothesis formulated at the beginning of this paper requires $\gamma<0$ and $\eta<0$.

The supply of labor is always observed due to the manner in which the data are collected. Individuals who are not working are asked if they are looking for work. The same does not hold true for the demand for labor. According to this model, $\mathrm{E}^{\mathrm{D}}$ is only observed when employment is less than $.96 \mathrm{LF}$. Therefore, the model was estimated only using observations where $\mathrm{E}<.96 \mathrm{LF}$. Substituting in the cost of hiring and searching, and replacing $\mathrm{E}$ with $\mathrm{E}^{\mathrm{D}}$ yields the following:

$$
\begin{aligned}
& \mathrm{E}^{\mathrm{D}}=\left(\pi_{1}+\beta_{1}\right)+\beta_{2} \mathrm{~W}+\gamma \eta\left(\mathrm{LF}-\mathrm{E}^{\mathrm{D}}\right)+\beta_{3} \mathrm{Z}+\left(\varepsilon_{1}+\gamma \varepsilon_{3}\right) \\
& \mathrm{LF}=\left(\pi_{2}+\mathrm{b}_{1}\right)+\mathrm{b}_{2} \mathrm{~W}-\theta \alpha\left(\mathrm{LF}-\mathrm{E}^{\mathrm{D}}\right)+\mathrm{b}_{3} \mathrm{~F}+\left(\varepsilon_{2}+\theta \varepsilon_{4}\right)
\end{aligned}
$$

or

$$
\begin{aligned}
& \mathrm{E}^{\mathrm{D}}=\mathbf{1}+\mathcal{1} \boldsymbol{T}_{[}\left[\beta_{1}^{1}+\beta_{2} \mathrm{~W}+\gamma \eta \mathrm{LF}+\beta_{3} \mathrm{Z}+\varepsilon_{1}+\gamma \varepsilon_{3}\right] \\
& \mathrm{LF}=\frac{1}{1+\theta \alpha}\left[\mathrm{b} \mathrm{t}+\mathrm{b}_{2} \mathrm{~W}+\theta \alpha \mathrm{E}^{\mathrm{D}}+\mathrm{b}_{3} \mathrm{~F}+\varepsilon_{2}+\theta \varepsilon_{4}\right]
\end{aligned}
$$

In most macro-econometric models, the supply of labor is a function of the demand for labor: as employment demand rises, the labor force increases and vice versa (the discouraged worker effect). In the proposed model, the relationship becomes simultaneous: $\mathrm{E}^{\mathrm{D}}$ affects LF but $L F$ also affects $E^{D}$. Measuring the effect $E^{\mathrm{D}}$ has on $L F$ without taking into account the effect $L F$ has on $\mathrm{E}^{\mathrm{D}}$ would produce a biased estimate. Increasing $\mathrm{E}^{\mathrm{D}}$ increases $\mathrm{LF}$ but an increase in LF further stimulates $\mathrm{E}^{\mathrm{D}}$ (see Figure 4). 


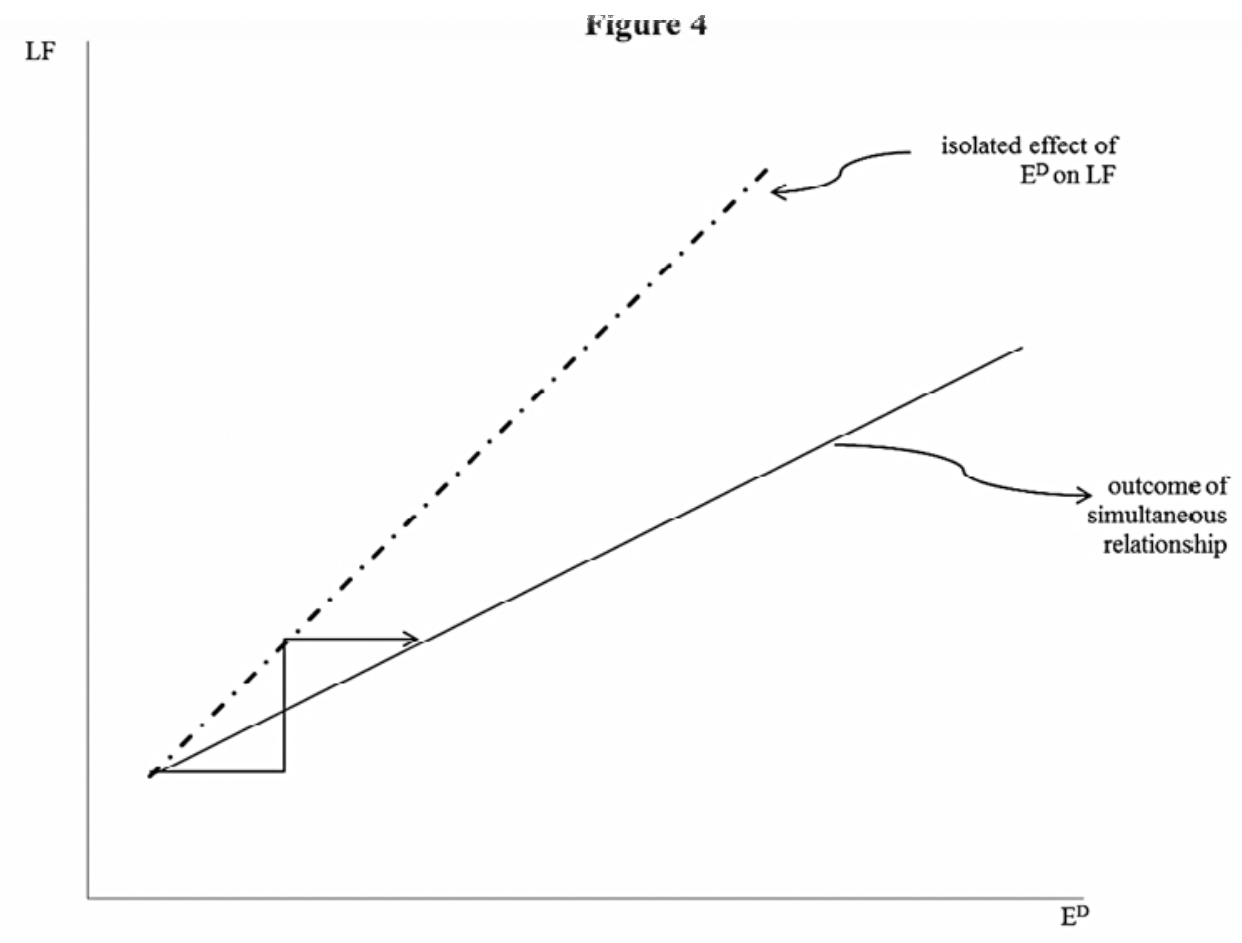

Thus ignoring the simultaneous nature of the relationship yields estimates which underestimate the effect of $E^{\mathrm{D}}$ on LF. Similarly, measuring the effect of $\mathrm{LF}$ on $\mathrm{E}^{\mathrm{D}}$ by itself would produce a downward biased estimate.

The equations which were estimated, along with all instrumental variables used in the first stage regression, are presented below:

$$
\begin{aligned}
& \mathrm{E}^{\mathrm{D}}=\frac{1}{1+\gamma \tau_{7}}\left[\beta_{1}^{1}+\beta_{2} \mathrm{~W}+\gamma \eta \mathrm{LF}+\beta_{3} \mathrm{Y}+\beta_{4} K_{t-1}+\varepsilon_{1}+\gamma \varepsilon_{3}\right]
\end{aligned}
$$

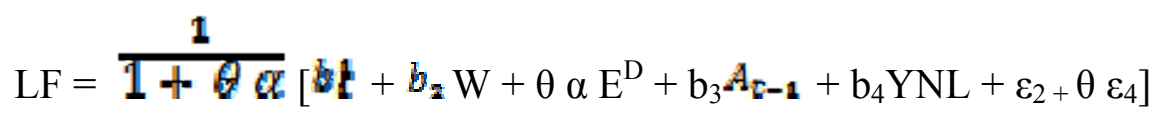

$$
\begin{aligned}
& \mathrm{Y}=\mathrm{f}\left(\mathrm{LF}, \mathrm{HJG}, \mathrm{RD}_{\mathrm{t}-1}, \mathrm{VBG}_{\mathrm{t}-1}, \mathrm{XG}, \mathrm{RBILL}_{\mathrm{t}-1}, \mathrm{M1}_{\mathrm{t}-1}, \mathrm{M1}_{\mathrm{t}-2}, \mathrm{~V}_{\mathrm{t}-1}, \mathrm{~V}_{\mathrm{t}-2}, \mathrm{D} 593, \mathrm{D} 594, \mathrm{D} 601\right) \\
& \mathrm{W}=\mathrm{f}\left(\mathrm{LF}-\mathrm{E}, \mathrm{HJG}, \mathrm{RD}_{\mathrm{t}-1}, \mathrm{VBGt}_{-1}, \mathrm{YGP}_{\mathrm{T}} \mathrm{T}, \mathrm{PIM}, \mathrm{RBILL}_{\mathrm{t}-1}, \mathrm{M1}_{\mathrm{t}-1}, \mathrm{M1}_{\mathrm{t}-2}\right)
\end{aligned}
$$


Where

$\mathrm{Y}=$ output

$\mathrm{K}=$ the capital stock

$\mathrm{A}=$ value of nondemand deposit securities

$\mathrm{YNL}=$ nonlabor income of households

$\mathrm{HJG}=$ man-hours employed by the government

$\mathrm{RD}=$ the discount rate

$\mathrm{VBG}=$ value of government securities

$\mathrm{XG}=$ purchases of goods by the government

RBILL $=$ three-month treasury bill rate

M1 = money supply

$\mathrm{V}=$ stock of inventories

D593, 4, 601 = dummy variables to capture effect of steel strike in 1959

$\mathrm{T}=$ time

PIM = implicit price deflator for imports

The data used to estimate the model are the quarterly data used by Fair in estimating his macroeconomic model. These data were collected for the 1952-I to 1977-I period. A detailed description of how the variables were constructed and adjusted can be found in his book.

The demand for labor is a function of the wage rate, the cost of hiring, the amount of output that is to be produced, and the amount of capital stock available. The supply of labor is a function of the wage rate, the cost of finding employment, the value of nondemand deposit securities, and nonlabor income.

$\mathrm{Y}$ and $\mathrm{W}$ are endogenous in the model. The tightness of the labor market affects $\mathrm{W}$ and the decision as to how much to produce is affected by the amount of available labor. A, YNL, and $\mathrm{K}$ are assumed to be exogenous variables. Two-stage-least squares is the appropriate 
estimation technique to be used. In the first stage, $E^{\mathrm{D}}, \mathrm{LF}, \mathrm{Y}$, and $\mathrm{W}$ are regressed on a set of exogenous variables. The predicted values are then used to estimate the $\mathrm{E}^{\mathrm{D}}$ and $\mathrm{LF}$ equations.

The set of exogenous variables are variables that are thought to affect the endogenous variables in the model, but are not themselves affected by the process described by the model. The following assumptions were used in defining this set. Government policy variables were assumed to be exogenous. This includes both fiscal policies and policies controlled by the FED. The implicit price deflator for imports was assumed to be determined abroad. The stock of inventories in the previous period was assumed to affect the decision on how much to produce, but be unaffected by this decision. Finally, time and the constant term can be safely classified as exogenous.

The hypothesis which is being tested is that the demand for labor by firms is inversely related to the cost of hiring, and the cost of hiring decreases with the supply of available labor. Referring back to the original structural specification of the model, verification of the hypothesis necessitates both $\gamma$ and $\eta$ to be negative. In the estimating equation for $E^{\mathrm{D}}$, these two coefficients enter multiplicatively as the coefficient of LF. Therefore, the test of the hypothesis is whether the coefficient of LF, $\gamma \eta$, is significantly greater than 0 . The results are presented below. 


\begin{tabular}{|c|c|}
\hline \multicolumn{2}{|c|}{ Table 1 } \\
Dependent Variable: $\mathrm{E}^{\mathrm{D}}$ \\
\hline Explanatory variables & $\begin{array}{c}\text { Estimated coefficients } \\
\text { (t-stats in parentheses) }\end{array}$ \\
\hline C & $\begin{array}{l}-12473.5 \\
(-.974373)\end{array}$ \\
\hline W & -76.2236 \\
& $(-3.59428)$ \\
\hline LF & 1.18090 \\
& $(4.32941)$ \\
\hline Y & 43.0529 \\
& $(3.36011)$ \\
\hline Standard error of regression=532.724 \\
\hline
\end{tabular}

The coefficient of LF is significantly greater than 0 , supporting the hypothesis. The coefficient on LF is 1.18 implying that an increase of a thousand in the size of the labor force increases the demand for employment by more than a thousand.

Table 2 gives the results from estimating the labor supply equation. 


\begin{tabular}{|c|c|}
\hline \multicolumn{2}{|c|}{$\begin{array}{c}\text { Table } 2 \\
\text { Dependent Variable: LF }\end{array}$} \\
\hline Explanatory variables & $\begin{array}{c}\text { Estimated coefficients } \\
\text { (t-stats in parentheses) }\end{array}$ \\
\hline $\mathrm{C}$ & $\begin{array}{l}.547393 \\
(38.6514)\end{array}$ \\
\hline $\mathrm{W}$ & $\begin{array}{c}.192790 \mathrm{E}-03 \\
(1.76057)\end{array}$ \\
\hline $\mathrm{E}$ & $\begin{array}{c}.117375 \mathrm{E}-05 \\
(3.60197)\end{array}$ \\
\hline $\mathrm{A}_{\mathrm{t}-1}$ & $\begin{array}{l}-1.92100 \\
(-2.76091)\end{array}$ \\
\hline YNL & $\begin{array}{l}-144.298 \\
(-3.21963)\end{array}$ \\
\hline Standard error of regres & $=.353186 \mathrm{E}-02$ \\
\hline
\end{tabular}

The coefficient of $\mathrm{E}$ is significant but small. Its direction supports the "discouraged worker effect" hypothesis. I would expect the magnitude of this effect to be larger if this equation were estimated separately on secondary workers.

In addition to testing the effect of hiring costs on the demand for labor, I am also testing the simultaneity of the demand-for-labor - supply-of-labor relationships. I speculated that estimating either relationship separately would result in underestimates of the effect of E on LF 
and the effect of LF on E. Therefore, it is interesting to compare the above results with ones obtained estimating the two equations using OLS.

\begin{tabular}{|c|c|}
\hline \multicolumn{2}{|c|}{ Table 3 } \\
Dependent Variable: $\mathrm{E}^{\mathrm{D}}$ \\
\hline Explanatory variables & $\begin{array}{c}\text { Estimated coefficients } \\
\text { (t-stats in parentheses) }\end{array}$ \\
\hline $\mathrm{C}$ & $\begin{array}{c}-733.537 \\
(-867369 \mathrm{E}-01)\end{array}$ \\
\hline $\mathrm{W}$ & $\begin{array}{l}-57.8625 \\
(-3.74513)\end{array}$ \\
\hline $\mathrm{LF}$ & $\begin{array}{l}.929552 \\
(5.16513)\end{array}$ \\
\hline $\mathrm{Y}$ & $\begin{array}{l}54.1967 \\
(5.38678)\end{array}$ \\
\hline $\mathrm{K}$ t-1 & $\begin{array}{l}-5.69937 \\
(-.653741)\end{array}$ \\
\hline
\end{tabular}

\begin{tabular}{|c|c|}
\hline \multicolumn{2}{|c|}{ Table 4 } \\
Dependent Variable: LF \\
\hline Explanatory variables & $\begin{array}{c}\text { Estimated coefficients } \\
\text { (t-stats in parentheses) }\end{array}$ \\
\hline C & $\begin{array}{c}.542368 \\
(40.1506)\end{array}$ \\
\hline W & $\begin{array}{c}.174064 \mathrm{E}-03 \\
(1.65337)\end{array}$ \\
& $\begin{array}{c}128971 \mathrm{E}-05 \\
(4.16490)\end{array}$ \\
\hline $\mathrm{E}$ & $\begin{array}{c}-2.03163 \\
(-3.00952)\end{array}$ \\
\hline $\mathrm{A} t-1$ & $\begin{array}{c}-147.772 \\
(-3.32786)\end{array}$ \\
\hline
\end{tabular}

As previously hypothesized, estimating the effect of the supply of labor on $\mathrm{E}^{\mathrm{D}}$ without taking into account the feedback from employment to labor supply leads to a smaller estimated coefficient. However, this was not found to be true for estimating the effect of employment on LF without controlling for the simultaneity.

I next tested the exogeneity of some of the instruments used in the 2SLS regressions. If all the variables used as instruments were truly exogenous to the model, then deleting some would yield less efficient estimates, but the estimated coefficients would be about the same. In 
the first run (Table 5), I took out the stock of inventories as an instrument. In the second run (Table 6), I deleted the variables controlled by the FED.

Table 5: Excluding Stock of Inventories

\begin{tabular}{|c|c|}
\hline \multicolumn{2}{|c|}{ Dependent Variable: $\mathrm{E}^{\mathrm{D}}$} \\
\hline Explanatory variables & $\begin{array}{c}\text { Estimated coefficients } \\
\text { (t-stats in parentheses) }\end{array}$ \\
\hline $\mathrm{C}$ & -10817.4 \\
& $(-.818556)$ \\
\hline $\mathrm{W}$ & -74.1732 \\
& $(-3.41364)$ \\
\hline $\mathrm{LF}$ & 1.14652 \\
& $(4.07337)$ \\
\hline $\mathrm{Y}$ & 42.4379 \\
& $(3.28276)$ \\
\hline $\mathrm{K}_{\mathrm{t}-1}$ & -12.4441 \\
& $(-1.01029)$ \\
\hline
\end{tabular}

\begin{tabular}{|c|c|}
\hline \multicolumn{2}{|c|}{ Dependent Variable: LF } \\
\hline Explanatory variables & $\begin{array}{l}\text { Estimated coefficients } \\
\text { (t-stats in parentheses) }\end{array}$ \\
\hline $\mathrm{C}$ & $\begin{array}{r}.547674 \\
(37.8321) \\
\end{array}$ \\
\hline $\mathrm{W}$ & $\begin{array}{c}.194601 \mathrm{E}-03 \\
(1.74799)\end{array}$ \\
\hline $\mathrm{E}$ & $\begin{array}{c}.116706 \mathrm{E}-05 \\
(3.49826)\end{array}$ \\
\hline$A_{t-1}$ & $\begin{array}{l}-1.91083 \\
(-2.71105)\end{array}$ \\
\hline YNL & $\begin{array}{l}-144.504 \\
(-3.21841) \\
\end{array}$ \\
\hline
\end{tabular}

Table 6: Excluding Variables Controlled by the Fed

\begin{tabular}{|c|c|}
\hline \multicolumn{2}{|c|}{ Dependent Variable: $\mathrm{E}^{\mathrm{D}}$} \\
\hline Explanatory variables & $\begin{array}{c}\text { Estimated coefficients } \\
\text { (t-stats in parentheses) }\end{array}$ \\
\hline $\mathrm{C}$ & -12457.3 \\
& $(-.725395)$ \\
\hline $\mathrm{W}$ & -76.8727 \\
& $(-2.96526)$ \\
\hline $\mathrm{LF}$ & 1.18175 \\
& $(3.22290)$ \\
\hline $\mathrm{Y}$ & 40.5767 \\
& $(2.65139)$ \\
\hline $\mathrm{K}_{\mathrm{t}-1}$ & -13.5421 \\
& $(-.854673)$ \\
\hline
\end{tabular}

\begin{tabular}{|c|c|}
\hline \multicolumn{2}{|c|}{ Dependent Variable: LF } \\
\hline Explanatory variables & $\begin{array}{l}\text { Estimated coefficients } \\
\text { (t-stats in parentheses) }\end{array}$ \\
\hline $\mathrm{C}$ & $\begin{array}{l}.546265 \\
(37.5763) \\
\end{array}$ \\
\hline $\mathrm{W}$ & $\begin{array}{c}.142233 \mathrm{E}-03 \\
(1.23762)\end{array}$ \\
\hline $\mathrm{E}$ & $\begin{array}{c}.121164 \mathrm{E}-05 \\
(3.61053)\end{array}$ \\
\hline$A_{t-1}$ & $\begin{array}{l}-2.18776 \\
(-3.03247)\end{array}$ \\
\hline YNL & $\begin{array}{l}-120.673 \\
(-2.60156)\end{array}$ \\
\hline
\end{tabular}


In all cases, the estimated standard error increases. The estimated coefficients change, but never radically. To more rigorously test for specification error, the estimates obtained using all the instrumental variables, $\mathbb{R}_{0}$, should be compared with the estimated coefficients deleting questionable instruments, $\vec{\beta}$. A test statistic can be formed with is distributed asymptotically as central $\chi^{2}$ where $\mathrm{K}$ is the number of unknown parameters in $\beta$ when no misspecification occurs (Hausman specification test).

As a final step, I adjusted for serial correlation, which was indicated in the previous 2SLS regressions. Correcting for serial correlation using all the instruments used in the previous regressions would have produced inefficient estimates, given the number of observations. The minimum number of instruments were used that assured consistency. The results are given below:

Table 8: Correcting for Serial Correlation

\begin{tabular}{|c|c|}
\hline \multicolumn{2}{|c|}{ Dependent Variable: $\mathrm{E}^{\mathrm{D}}{ }^{*}$} \\
\hline Explanatory variables & $\begin{array}{c}\text { Estimated coefficients } \\
\text { (t-stats in parentheses) }\end{array}$ \\
\hline $\mathrm{C}$ & -55151.1 \\
& $(-2.16626)$ \\
\hline $\mathrm{W}$ & -145.565 \\
& $(-2.70783)$ \\
\hline $\mathrm{LF}$ & 2.05157 \\
& $(3.83907)$ \\
\hline $\mathrm{Y}$ & 45.1980 \\
& $(1.71301)$ \\
\hline $\mathrm{K}_{\mathrm{t}-1}$ & -57.1612 \\
& $(-2.51495)$ \\
\hline \multicolumn{2}{|c|}{} \\
\hline *Estimated rho=.823289; standard error=.067 \\
\hline
\end{tabular}

\begin{tabular}{|c|c|}
\hline \multicolumn{2}{|c|}{ Dependent Variable: $\mathrm{LF}^{*}$} \\
\hline Explanatory variables & $\begin{array}{c}\text { Estimated coefficients } \\
\text { (t-stats in parentheses) }\end{array}$ \\
\hline $\mathrm{C}$ & $\begin{array}{c}.606891 \\
(15.3533)\end{array}$ \\
\hline $\mathrm{W}$ & $\begin{array}{c}240589 \mathrm{E}-03 \\
(1.49625)\end{array}$ \\
\hline $\mathrm{E}$ & $\begin{array}{c}-.341568 \mathrm{E}-06 \\
(-.445842)\end{array}$ \\
\hline $\mathrm{A}_{\mathrm{t}-1}$ & $\begin{array}{c}0.64027 \\
(-.884826)\end{array}$ \\
\hline $\mathrm{YNL}$ & $\begin{array}{c}11.5640 \\
(.413983)\end{array}$ \\
\hline *Estimated rho $=.861531 ;$ standard error $=.06$ \\
\hline
\end{tabular}


The original hypothesis is still supported by the estimated coefficient for LF in the demand for labor equation after correcting for serial correlation. However, all but one of the estimated coefficients in the labor supply equation become insignificant after correcting for serial correlation.

A serious problem remains in estimating the proposed model: the demand for labor is not observed beyond a certain point. Because of this, the model was estimated only on those values for which $\mathrm{E}<.96 \mathrm{LF}$. Thus, the dependent variable for the employment demand equation is truncated. The situation is depicted in the following diagram (Figure 5). The $\mathrm{E}(\varepsilon \mid \mathrm{X})<0$ using only observations for which : $\mathrm{E}^{\mathrm{D}}<.96 \mathrm{LF}$, and all estimated coefficients will be inconsistent. This is not a problem for the labor supply since the dependent variable is always observed.

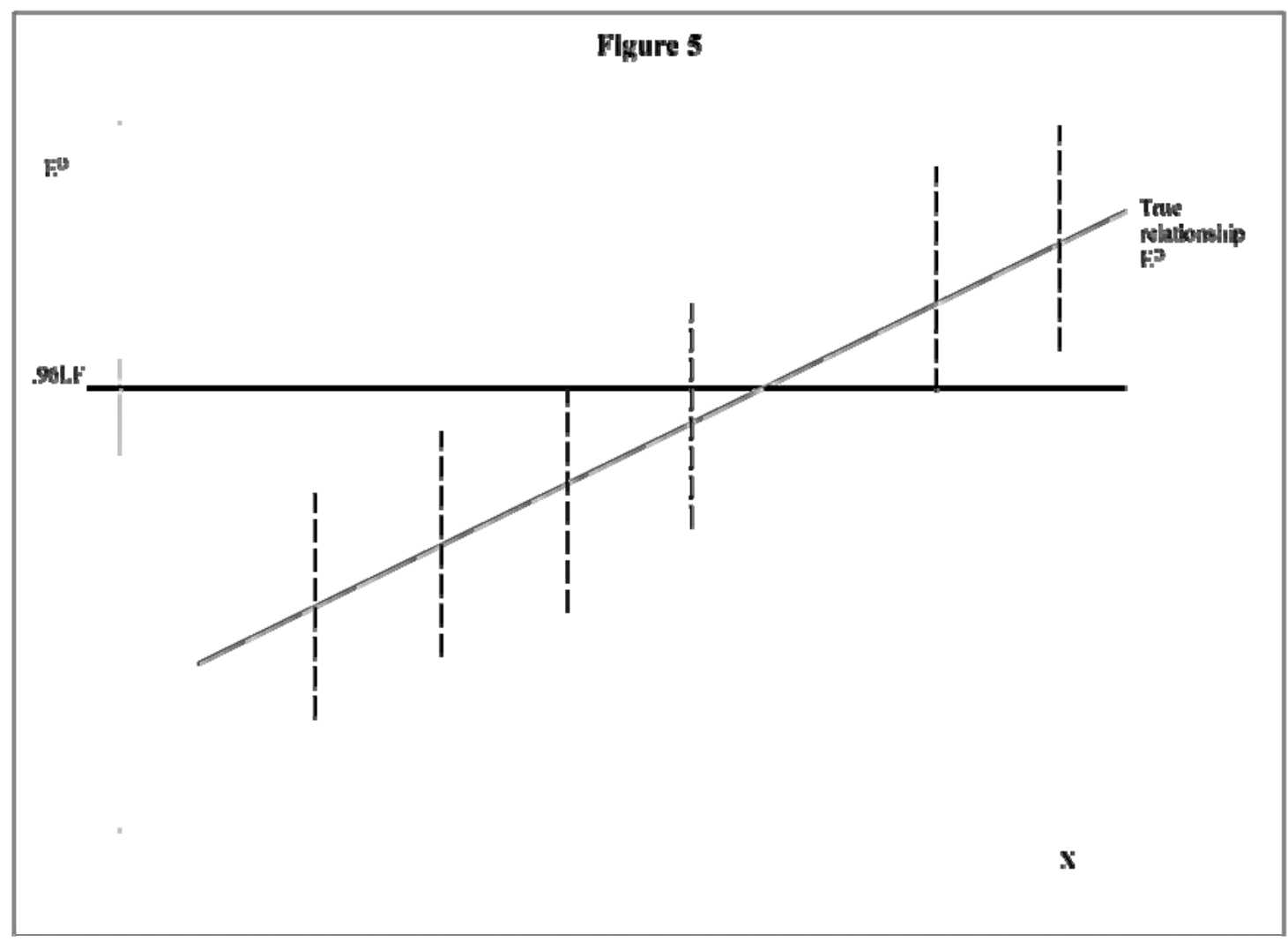


In order to estimate the demand for labor equation, a tobit model could be used. The likelihood function to be maximized would be

$$
L=\pi \frac{1}{\sigma} f\left(\frac{E^{D}-\gamma Y-\beta X}{\sigma}\right) \pi\left[1-F^{\prime \prime}\left(\frac{96 L F^{\prime}-\gamma Y-\beta X}{\sigma}\right)\right]
$$

where $\mathrm{Y}$ is a vector of the endogenous variables in the equation and $\mathrm{X}$, the exogenous variables. The problem with this is that $\mathrm{Y}$ is correlated with the error term. Maximizing $\mathrm{L}$ would thus produce inconsistent estimates. Therefore, the expression in $\mathrm{L}$ must be $\mathrm{E}^{\mathrm{D}}$ minus its reduced form. Then the question would be whether the structural coefficients for $\mathrm{E}^{\mathrm{D}}$ could be retrieved from the coefficients maximized in the likelihood function. This is possible since the estimated structural coefficients from the supply-for-labor equation are available.

As a final note, a simple procedure could have been performed to test the assumption that $\mathrm{E}=\mathrm{E}^{\mathrm{D}}$ when $\mathrm{E}<.96 \mathrm{LF}$. The demand for labor equation could have been estimated on another set of observations assuming a different truncation point, say .95LF. If the demand for employment were only observed until $\mathrm{E}=.95 \mathrm{LF}$, then the estimated coefficients would be lower for the estimated equation assuming $\mathrm{E}^{\mathrm{D}}$ is observed until employment equals $96 \%$ of the labor force.

In conclusion, the hypothesis that the demand for employment is positively affected by the supply of available labor has been supported. I postulated that this effect acted through the process of lowering hiring costs. 